\title{
Studies on iron-chromium redox storage system
}

\author{
S H PAWAR, R D MADHALE, P S PATIL and C D LOKHANDE \\ Department of Physics, Shivaji University, Kolhapur 416004 , India
}

\begin{abstract}
The performance of the redox storage battery based on the $\mathrm{Fe}-\mathrm{Cr}$ redox couple is studied in charging and discharging modes of the system. The stability of each charged species is determined by measuring the variation of half-cell potential with time. The spectra of the electrolytes are recorded before and after charging of the system. The effect of atmosphere on the charged species has also been investigated.
\end{abstract}

Keywords. Photochemical storage system; iron-chromium redox couples.

\section{Introduction}

In recent years redox battery systems have generated interest as an energy storage system. A redox flow cell (or battery) (Giner et al 1976; Beccu and Crespy 1976; Ciprois et al 1977; Thaller. 1977, 1979; Butler et al 1979; Savinelli et al 1979; Warshay and Wright 1977) is one in which the chemical species participate in storing electrical energy and regenerate the energy when needed. The cell is charged with the input of electrical energy to drive the overall cell reaction. The oxidized species are produced in one half-cell (anodic compartment) and the reduced species are formed in another half-cell (cathodic compartment).

A number of redox couples have been proposed for such systems. These include $\mathrm{Fe}(\mathrm{III}) / \mathrm{Fe}$ (II) $(\mathrm{HCl})$ (Thaller 1977, 1979); $\mathrm{Cr}(\mathrm{III}) / \mathrm{Cr}(\mathrm{II})(\mathrm{HCl})(\mathrm{Beccu}$ and Crespy 1976; Thaller 1977, 1979: Ti(IV)/Ti(III) (Savinelli et al 1979); $\mathrm{Br}_{2} \mathrm{Br}^{-}$(Gileadi et al 1977: Yeo and McBreen 1979) and for PEC cells, $\mathrm{S}_{2}^{2-}, \mathrm{S}_{x}^{2-}$ and $\mathrm{Se}^{2-} \cdot \mathrm{Se}_{2}^{2-}$ (Ellis et al 1976; Miller and Heller 1976). Out of these couples, Fe-Cr redox system (Thaller 1979: Thaller 1979) seems to be promising due to its high value of electrochemical potential $\left(E^{0}=1 \cdot 18 \mathrm{~V}\right)$.

Chen et al (1981) studied iron (III), and iron (II) complexes with O-phenanthroline and related ligands as solution redox couples for electrochemical energy storage. They found that the complexation with $\mathrm{O}$-phenanthroline or bipyridyl-type ligands results in significant positive shifts in the potential of the redox couple. Liu et al (1981) revealed that the approach of using a chelating agent in the anolyte for an FeTi redox system shows only marginal improvement in cell discharge performance. However, the application of a solid reducing agent in the anolyte, particularly lead, enhanced the performance of the redox system.

In recent years solar energy is converted into electrical energy by photochemical conversion with semiconductor liquid junction cells. The efficiencies achieved with these cells are comparable to that of solid state junction cells. Energy can be stored with semiconductor liquid junction cells by using photoelectrochemical redox storage cells. The oxide semiconductors are stable and suitable for photoelectrochemical redox storage cells. The $\alpha-\mathrm{Fe}_{2} \mathrm{O}_{3}$ semiconductor electrode is attracted in the PEC cell due to its comparatively low band gap energy than that of $\mathrm{TiO}_{2}$ and $\mathrm{SrTiO}_{3} \cdot \mathrm{K}_{4} \mathrm{Fe}(\mathrm{CN})_{6}$ is the most suitable redox electrolyte in PEC cells formed with $\alpha-\mathrm{Fe}_{2} \mathrm{O}_{3}$ electrode.

In the present investigation, an attempt was made to form a redox storage cell 
with $\mathrm{K}_{4} \mathrm{Fe}(\mathrm{CN})_{6}$ and $\mathrm{CrCl}_{3}$. The electrode potential of the solutions before and after charging was measured and it is found that the formal potential of the couple is sufficiently shifted towards the desired direction. Spectrophotometric studies reveal the charging of the system. Moreover this system shows improved characteristics with respect to stability when it is air-tight.

\section{Experimental}

The schematic diagram of the redox storage cell is shown in figure 1. Two beakers are connected by the conducting bridge, $19 \mathrm{~cm}$ in length, formed with agar-agar gel. The first compartment of the cell consists of $\mathrm{K}_{4} \mathrm{Fe}(\mathrm{CN})_{6}$ solution in which oxidation takes place. The other compartment consists of $\mathrm{CrCl}_{3}$ solution in which reduction takes place.

The cell was charged with external electricity. The electrical characteristics of the mode of charging and discharging were studied with circuits shown in figures la and $1 \mathrm{~b}$ respectively.

Spectrophotometric studies have been carried out by using a spectrophotometer (Hitachi 330) in the ultraviolet and visible wavelength. The spectra of the redox solutions before and after charging were recorded in the wavelength range of 350 to $600 \mathrm{~nm}$. The studies were carried out using $0 \cdot 1 \mathrm{M}$ concentration of the electrolytes. The durability of the system is greater when the system is air-tight.

\section{Results and discussion}

In order to study the mode of changing, the flow of electrons in terms of current is
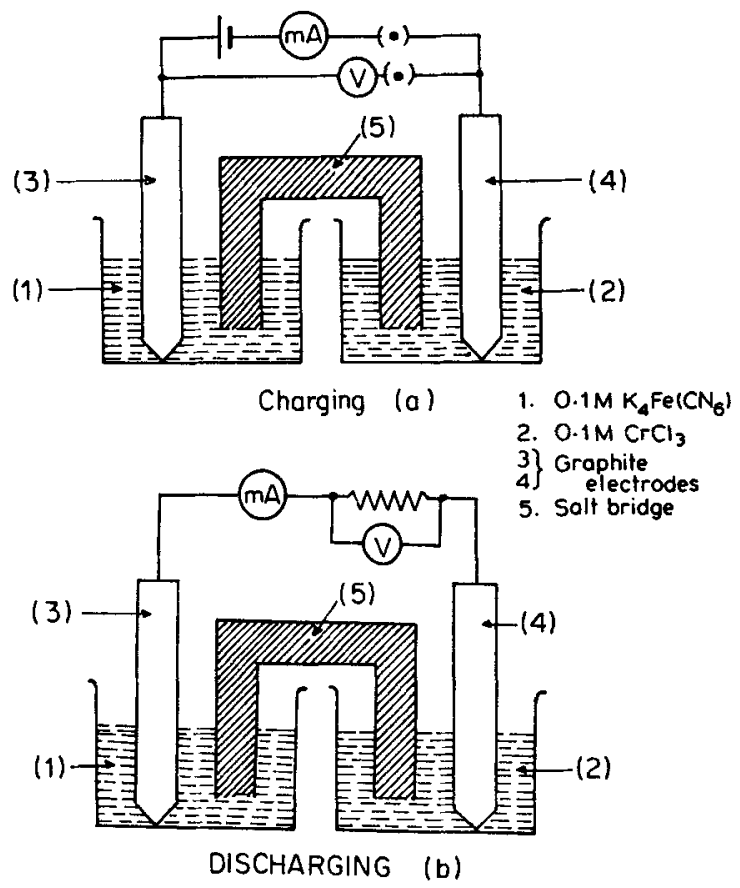

Figure 1. Redox storage cell. 
measured with time. The variation of current with time is shown in figure 2 . The current decreases with charging time attaining a steady state value. The open circuit voltage of the system is also found to change from $0.2 \mathrm{~V}$ to $0.8 \mathrm{~V}$ as shown in figure 2 . The associated electrode reactions during charging are

$$
\begin{aligned}
& \mathrm{Fe}^{2+}+h^{+} \ldots \ldots-\mathrm{Fe}^{+3} \text { at anode, } \\
& \mathrm{Cr}^{+3}+e^{-} \ldots \ldots-\mathrm{Cr}^{+2} \text { at cathode. }
\end{aligned}
$$

Thus electrical energy is stored in the form of chemical species. The nature of plots in figure 2 shows that the rate of charging of the redox storage cell is not constant but decreases exponentially. The plot of $\ln I$ versus time is linear (figure 3).

When electricity is cut off the cell is allowed to discharge through load resistance $R L=33 \mathrm{~K} \Omega$. The voltage is measured across $R L$ and the current is measured in the series of the circuit (figure $1 \mathrm{~b}$ ). The variations of discharging current and voltage with time are shown in figure 4 . It is seen that both the voltage and current decrease with time and attain the original values after $90 \mathrm{~min}$ of discharge. In the discharge mode

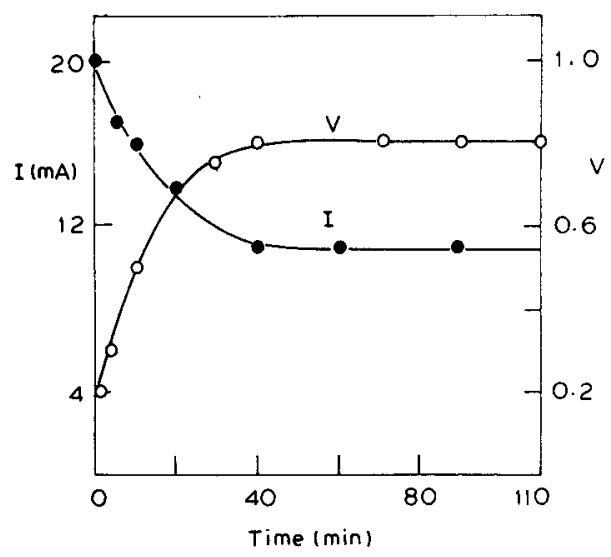

Figure 2. Current-voltage characteristics of redox storage cell formed with $\mathrm{K}_{\mathbf{4}} \mathrm{Fe}(\mathrm{CN})_{6}$ and $\mathrm{CrCl}_{3}$ during charging.

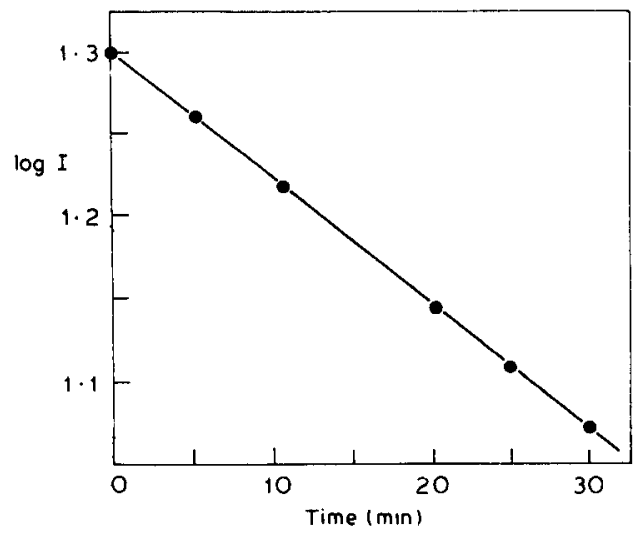

Figure 3. Variation of $\log I$ versus time. 


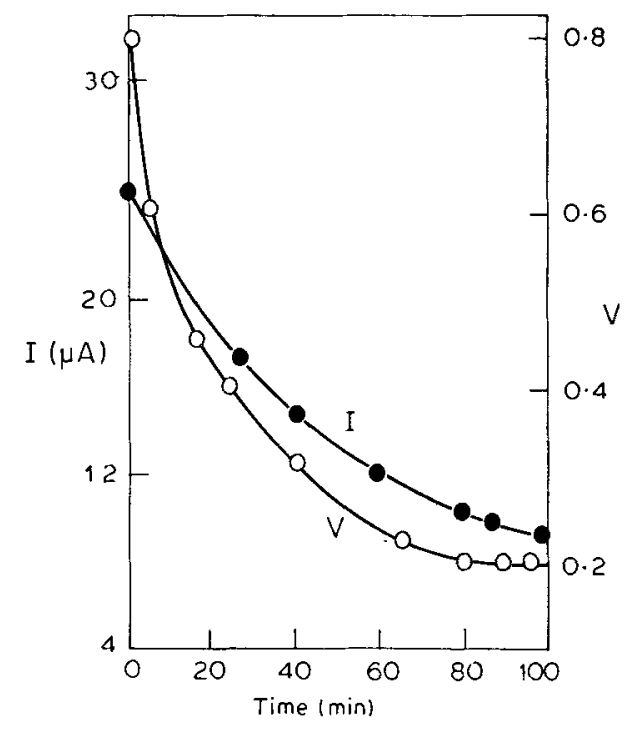

Figure 4. Variation of discharging current and voltage with time formed with $\mathrm{K}_{4} \mathrm{Fe}(\mathrm{CN})_{6}$ and $\mathrm{CrCl}_{3}$.

Table 1. Half cell potentials.

\begin{tabular}{lcc}
\hline System & $\begin{array}{c}\text { Before charging } \\
V \text { vs SCE }\end{array}$ & $\begin{array}{c}\text { After charging } \\
V \text { vs SCE }\end{array}$ \\
\hline $\begin{array}{l}0.1 \mathrm{M} \mathrm{K}_{4} \mathrm{Fe}(\mathrm{CN})_{6} \\
\text { in water }\end{array}$ & $-0.092 \mathrm{~V}$ & $-0.203 \mathrm{~V}$ \\
$\begin{array}{l}0.1 \mathrm{M} \mathrm{CrCl}_{3} \\
\text { in } 2 \mathrm{~N} \mathrm{HCl}\end{array}$ & $-0.488 \mathrm{~V}$ & $+0.467 \mathrm{~V}$ \\
\hline
\end{tabular}

the following reactions take place:

$$
\begin{array}{lll}
\mathrm{Fe}^{+3} & \ldots-\mathrm{Fe}^{+2}+h^{+}, \\
\mathrm{Cr}^{+2} & \ldots-\cdots \mathrm{Cr}^{+3}+e^{-} .
\end{array}
$$

The life-time of the charged species was studied by measuring the potential of the redox cell. The cell voltage decreases with time and about 8 to 10 hours are required for redox species to get its original voltage and about 105 minutes for $\mathrm{Fe}^{+3}$ species to get its original voltage measured with respect to SCE before charging.

In order to understand the mechanism of charging and discharging of redox storage cell, we have measured the half-cell potentials of the two compartments with respect to SCE (table 1). It is seen that the values of both compartments change remarkably. This is attributed to the change in state of the chemical species.

The qualitative test of the charged species is carried out to confirm the change in the original species. The charged solution of $\mathrm{K}_{4} \mathrm{Fe}(\mathrm{CN})_{6}$ is tested by adding $\mathrm{AgNO}_{3}$ solution to it. An orange stuff is formed which indicates that the $\mathrm{K}_{4} \mathrm{Fe}(\mathrm{CN})_{6}$ containing $\mathrm{Fe}^{+2}$ species has changed into $\mathrm{K}_{4} \mathrm{Fe}(\mathrm{CN})_{6}$ containing $\mathrm{Fe}^{+3}$ species. In the case of $\mathrm{CrCl}_{3}$ solution it is tested with liquor ammonia as also with the solution of $\left(\mathrm{NH}_{4}\right)_{2} \mathrm{~S}$, 
which is the test for $\mathrm{Cr}^{+3}$ species. However, the charged $\mathrm{CrCl}_{3}$ solution forms precipitate with the above solutions. This indicates that the charging of the solution is due not merely to $\mathrm{Cr}^{+2}$ species but also to some other forms.

Further analysis was made with spectrophotometric measurements. It is observed that during charging the chromium solution changes from green to deep blue in colour. Johnson and Reid (1985) demonstrated spectrophotometrically that in aqueous solutions containing ( $\mathrm{Cr}$ (III) and chloride ions, three inner sphere complex ions are present: $\mathrm{Cr}\left(\mathrm{H}_{2} \mathrm{O}\right)_{4} \mathrm{Cl}^{+1}$ (green), $\mathrm{Cr}\left(\mathrm{H}_{2} \mathrm{O}\right)_{5} \mathrm{Cl}^{+2}$ (blue-green) and $\mathrm{Cr}\left(\mathrm{H}_{2} \mathrm{O}\right)_{6}^{+3}$ (blue)). These ions are relatively 'inert' i.e. they are very slow to exchange ligands in their coordination sphere. The $\left(\mathrm{K}_{4} \mathrm{Fe}(\mathrm{CN})_{6}\right)$ solution changes from pale yellow to yellow.

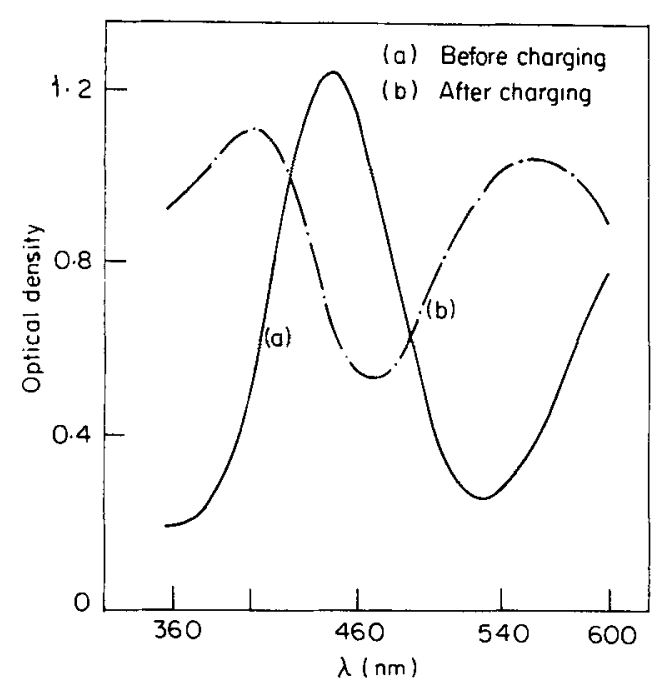

(5)

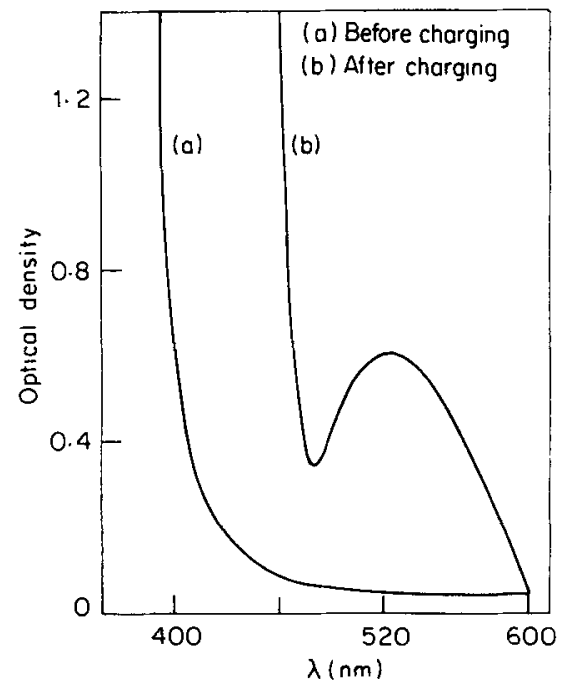

(6)

Figures 5 and 6. Spectra in the wavelength range of $360 \mathrm{~nm}$ to $600 \mathrm{~nm}$ before and after charging. 5. $\mathrm{CrCl}_{3}$ solution. 6. $\mathrm{K}_{4} \mathrm{Fe}(\mathrm{CN})_{6}$ solution.

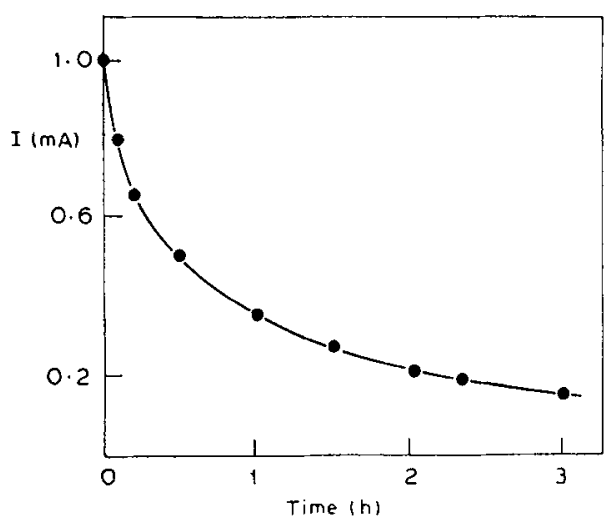

(7)

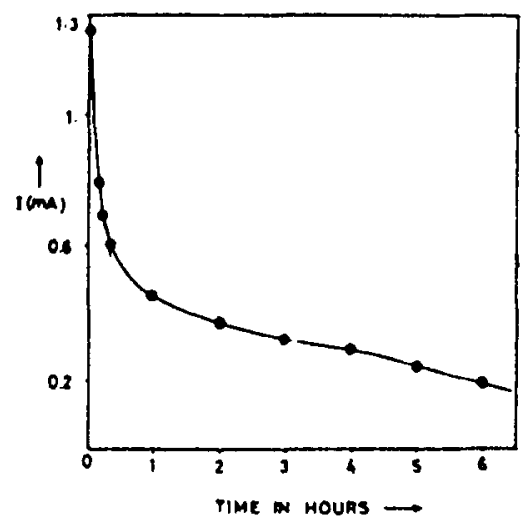

(8)

Figures 7 and 8. Variation of current with time when the system is 7. open. 8. air-tight. 
The spectra of the chromium solutions of the redox cell were characterized by two broad absorption bands with a maxima of $408-430 \mathrm{~nm}$ and $575-610 \mathrm{~nm}$. The spectra of the cell solutions are recorded before and immediately after charging in the wavelength range of 350 to $600 \mathrm{~nm}$. In $\mathrm{CrCl}_{3}$, for the first peak the $\lambda_{\max }$ changes from $445 \mathrm{~nm}$ to $405 \mathrm{~nm}$, and for the second peak, the $\lambda_{\max }$ changes from 610 to $570 \mathrm{~nm}$. $\mathrm{K}_{4} \mathrm{Fe}(\mathrm{CN})_{6}$ gives a steepline with $\lambda_{\max } 410 \mathrm{~nm}$ before charging and an additional peak is obtained with $\lambda_{\max } 520 \mathrm{~nm}$. The graphs are shown in figures 5 and 6 . The shifting in the $\lambda_{\max }$ after charging indicates that the species are charged.

Results with air-tight system show longer stability as compared to the open system. The graphs show that the current is extracted at least up to 3 hours when the system is open and for 6 hours when the system is air-tight (figures 7 and 8 ). Thus the stability of the system is enhanced when the system is air-tight.

\section{Acknowledgements}

The authors are thankful to Mr C H Bhosale for experimental help. They acknowledge financial support from the Department of Non-Conventional Energy Sources.

\section{References}

Beccu K D and Crespy G 1976 Large scale energy storage by means of dissolved redox flow systems, SPE Meeting, Grenoble, France

Butler J N, Giner J and Stark H 1979 Complex redox couples for energy storage, Project 72-7-2 of EPRI Chen Y W D, Santhanam K S and Bard A J 1981 J. Electrochem. Soc. 1281460

Ciprios C. Erskine Jr W and Grimes P G 1977 Redox bulk energy storage system. Study, (Cleveland, Ohio: NASA-Lewis Research Centre) Vols. 1 and 2, CR 135206

Ellis A B, Kaiser S W and Wrighton M S 1976 J. Am. Chem. Soc. 981635

Gileadi E, Srinivasan S, Salzano F J, Braun C, Beaufrere A, Gottsfeld S, Nuttal L J and Laconti A B 1977 J. Power Sources 2191

Giner J, Swette L and Cahill A 1976 Screening of redox couples and electrode materials (Cleveland, Ohio: NASA-Lewis Research Centre) CR 134705

Johnson D A and Reid M A 1985 J. Electrochem. Soc. 1321058

Liu C C, Galasco R I and Savinell R F 1981 J. Electrochem. Soc. 1281755

Miller B and Heller A 1976 Nature (London) 262680

Savinelli R F, Liu C C, Galasco R T, Chiang S H and Coetzee J F 1979 J. Electrochem. Soc. 126357

Thaller L H 1977 Redox flow and demonstration, Symposium on Load-levelling, Electrochemical Society, Atlanta, Georgia

Thaller L H 1979 Redox flow energy storage system, Terrestriạl energy systems Conference, American Institute of Aeronautics and Astronautics, Orlando, NASA-TM 79143 Florida, NASA-TM 79067

Thaller L H 1979 Fourteenth Intersociety Energy Conversion Engineering Conference, Boston, Masachussetts, NASA-TM 79186

Warshay M and Wright L 1977 J. Electrochem. Soc. 124173

Yeo R S and McBreen J 1979 J. Electrochem. Soc. 1261682 